\title{
PENGARUH BIMBINGAN PRIBADI-SOSIAL DENGAN PENDEKATAN \\ RATIONAL EMOTIVE THERAPY UNTUK MENINGKATKAN \\ INTERAKSI SOSIAL DENGAN TEMAN SEBAYA
}

\author{
Yuni Widyaningrum *) \\ Vitalis Djarot Sumarwoto **)
}

\begin{abstract}
Abstrak
Siswa dalam hidupnya mengemban dua tugas perkembangan, yaitu sebagai makhluk individu dan makhluk sosial. Sebagai makhluk individu, kehidupan siswa di sekolah tidak dapat dilepaskan dari individu lain, mengingat bahwa siswa juga sebagai makhluk ssial. Artinya, perkembangan siswa itu terjadi, sebagian ditentukan oleh hasil interaksi dengan sesama teman, yang salah satunya disebut teman sebaya. Proses interaksi dengan teman sebaya merupakan perwujudan dari proses komunikasi, yang diharapkan akan terjadi saling mempengaruhi, sehingga menimbulkan suatu perubahan sikap atau perilaku pada diri siswa tersebut.

Interaksi dengan teman sebaya yang efektif dapat dilakukan melalui layanan bimbingan pribadi-sosial, karena hakikat layanan bimbingan pribadi-sosial adalah membantu siswa dalam memecahkan masalah-masalah pribadi yang disebabkan oleh dampak pergaulan sosial. Layanan bimbingan pribadi-sosial diyakini dapat membantu perubahan sikap dalam diri individu (siswa), dan dikembangkan melalui pendekatan rasional emotif therapy. Beberapa perubahan sikap hasil dari layanan bimbingan pribadi-sosial dengan pendekatan rasional emotif therapy bersangkut paut dengan masalah pola pikir dan kehidupan perasaan siswa.
\end{abstract}

Kata Kunci: Bimbingan pribadi-sosial dengan pendekatan rational emotive therapy dan interaksi dengan teman sebaya

* Yuni Widyaningrum adalah Mahasiswa Program Studi Bimbingan dan Konseling Fakultas Ilmu Pendidikan IKIP PGRI Madiun.

** Vitalis Djarot Sumarwoto adalah Dosen Program Studi Bimbingan dan Konseling Fakultas Ilmu Pendidikan IKIP PGRI Madiun. 


\section{Pendahuluan}

Siswa dalam kehidupannya adalah individu yang secara kodrati mengemban dua tugas perkembangan, yaitu sebagai makhluk individu dan makhluk sosial. Sebagai makhluk individu, setiap siswa memiliki kebebasan untuk mengembangkan dirinya secara optimal, sesuai dengan potensi masing-masing.

Menurut Frans Von Magniz (1985) ada dua macam kebebasan, yaitu eksistensial dan sosial. Kebebasan eksistensi pada prinsipnya mencakup otonomi seseorang (individu) untuk menentukan dirinya dalam mengisi hidupnya, baik yang menyangkut masa kini dan masa yang akan datang. Kebebasan eksistensial mengandaikan kepemilikan keleluasaan diri dalam mengisi hidupnya. Kebebasan eksistensial tersebut dalam realitasnya dibatasi kebebasan sosial, yang dapat diartikan sebagai kebebasan eksistensial orang lain. Pernyataan tersebut memberi petunjuk bahwa realisasi optimalisasi pengembangan diri siswa (individu) itu memerlukan kehadiran orang lain di sekitarnya. Kehadiran orang lain (teman sebaya) memproyeksikan adanya kebebasan sosial atau kebebasan eksistensial orang lain membatasi kebebasan eksistensial siswa selaku individu, mengingat siswa makhluk sosial siswa tidak bisa hidup dan berkembang sendiri. Siswa butuh interaksi sosial, antara lain dengan teman sebaya, agar dirinya kian berkembang menjadi dirinya sendiri. Intensitas interaksi sosial siswa dengan teman sebaya merupakan salah satu wujud dimilikinya kemampuan serta ketrampilan dalam melakukan komunikasi dengan individu lain.

Secara umum interaksi sosial diartikan sebagai hubungan atau komunikasi dengan orang lain disekitarnya. Orang lain yang dimaksud dalam uraian ini adalah teman sebaya, yaitu setiap individu yang bisa ditemui dan diajak berkomunikasi sehari-hari di sekolah.

Tujuan pokok interaksi sosial dengan teman sebaya adalah bersama-sama membantu meningkatkan pertumbuhan dan perkembangan dirinya sesuai dengan keadaan yang sebenarnya (yang dimiliki oleh siswa itu sendiri). Konsekuensinya adalah apabila siswa kurang mampu melakukan interaksi sosial dengan teman sebaya, maka besar kemungkinannya akan mengganggu perkembangan sosial dan perkembangan diri siswa. Harapannya bahwa perkembangan siswa akan berjalan baik, yaitu ketika siswa mampu berinteraksi dengan teman sebaya di sekolah.

Beberapa penyebab siswa kurang mampu dan terampil dalam berinteraksi sosial dengan teman sebaya adalah (1) kurang mampu beradapatasi, (2) kurang percaya terhadap kemampuan dirinya, (3) perasaan minder, (4) memiliki perasaan bersalah (5) cenderung meremehkan orang lain. Apabila sikap interaksi sosial yang kurang baik (rendah) tetap dipertahankan siswa maka tidak menutup kemungkinan timbul masalah dalam dirinya, sehingga berpotensi menghambat tugas-tugas perkembangannya. 
Hasil observasi peneliti pada bulan September 2013, minggu ke-2 dan ke-3 terhadap siswa kelas XI MAN Dolopo yang berjumlah 132 orang, menunjukkan bahwa 76 siswa (68\%) memiliki interaksi sosial dengan teman sebaya yang kurang baik. Apabila situasi dan kondisi siswa seperti itu tidak segera dicarikan solusi, maka akan berpotensi menghambat perkembangan hidupnya. Salah satu solusi yang diyakini dapat membantu menuntaskan dan mengentaskan masalah yang dihadapi siswa tersebut adalah dengan menerapkan bimbingan pribadi-sosial melalui pendekatan rational emotive therapy. Pemilihan solusi tersebut sejalan dengan pendapat Ahmad Juntika (2006:15-16) yang pada hakikatnya menegaskan bahwa bimbingan sosial pribadi membantu individu menyelesaikan masalahmasalah sosial yang ada kaitannya dengan masalah pribadi. Penerapan bimbingan sosial pribadi dengan pendekatan rational emotive therapy dilakukan dengan cara menciptakan lingkungan yang kondusif, interaksi pembelajaran yang akrab, mengembangkan sistem pemahaman diri, dan sikap-sikap yang positif, serta kemampuan-kemampuan sosial pribadi yang tepat. Tujuan yang ingin dicapai adalah memperbaiki tindakan dalam melaksanakan interaksi sosial dengan teman sebaya pada diri siswa.

Pelaksanaan bimbingan sosial pribadi akan maksimal jika pendekatan yang digunakan sesuai dengan permasalahan diatas ialah menggunakan pendekatan rational emotive therapy. Menurut Ellis (dalam Hartono dan Boy 2012 : 131) pendekatan rational emotive therapy berasumsi bahwa kognisi, emosi dan berperilaku berinteraksi secara signifikan dan mempunyai hubungan sebab akibat.

Pada hakikatnya pendekatan rational emotive therapy mempunyai tujuan membelajarkan individu berfikir rasional ketika individu tersebut menghadapi suatu permasalahan yang sedang dialami. Kebiasaan diri berfikir irasional dapat merusak diri dan menumbuhkan sikap tidak toleransi terhadap lingkungannya. Individu dituntut bisa mengaktualisasi potensi dirinya seoptimal mungkin, dan dapat mengubah kepribadiannya dalam hubungan sosial secara baik.

Uraian di atas memberi penegasan bahwa secara teoritis bimbingan sosial pribadi dengan pendekatan rational emotive therapy dapat meningkatkan interaksi sosial dengan teman sebaya. Konkritnya adalah bahwa penerapan pendekatan rational emotive therapy dapat meningkatkan interaksi sosial dengan teman sebaya dengan baik, karena dengan seseorang (siswa) berinteraksi sosial maka siswa akan dapat: menyesuaikan dirinya terhadap lingkungannya, bertanggung jawab, berfikir positif terhadap teman sebayanya, serta menciptakan hubungan yang harmonis dengan lingkungan sekolah.

Indikator kualitas interaksi sosial dengan teman sebaya dapat digambarkan sebagai berikut: (1) terjalin komunikasi secara harmonis, (2) adanya sikap saling menghormati dan menghargai, (3) ada usaha saling mengembangkan, (4) timbul komunikasi yang nyaman dan damai dengan di lingkungannya. 
Berdasarkan uraian diatas maka peneliti merasa tertarik untuk mengkaji lebih mendalam tentang masalah yang dikemukakan dalam penelitian ini. Tujuan penelitian akan menjadi terarah maka diberi judul: "Pengaruh bimbingan pribadisosial melalui pendekatan rational emotive therapy untuk meningkatkan interaksi sosial dengan sebaya".

\section{Pembahasan}

\section{Bimbingan Pribadi Sosial Dengan Pendekatan Rational Emotive Therapy}

a. Pengertian Bimbingan Pribadi Sosial

Ahmad Juntika (2006:15) menyatakan bimbingan sosial pribadi merupakan bimbingan untuk membantu individu dalam menyelesaikan masalah-masalah sosial pribadi.

Winkel dan Sri Hastuti (2006: 118) menyatakan bahwa bimbingan pribadi sosial merupakan layanan yang membantu para individu untuk menghadapi keadaan batinnya sendiri, mengatur dirinya sendiri dalam kerohanian, perawatan jasmani, serta dalam membina hubungan kemanusiaan dengan sesama di berbagai lingkungan.

Bertolak dari beberapa pengertian di atas peneliti berpendapat bahwa inti bimbingan sosial pribadi adalah proses membantu individu (siswa) agar individu (siswa) yang dibantu mampu menghadapi dan memecahkan masalah-masalah sosial pribadi, seperti: penyesuaian diri, menghadapi konflik dan pergaulan secara mandiri, serta mengatur dirinya sendiri dalam kerohanian.

b. Tujuan Bimbingan Pribadi Sosial

Syamsu Yusuf dan Ahmad Juntika (2006: 14) menyatakan bahwa tujuan layanan bimbingan sosial pribadi antara lain agar siswa memiliki:

1) komitmen yang kuat dalam mengamalkan nilai-nilai keimanan dan ketakwaan kepada Tuhan Yang Maha Esa, baik dalam kehidupan pribadi, keluarga, dengan teman sebaya, sekolah maupun masyarakat pada umumnya.

2) sikap toleransi terhadap umat beragama lain, dengan saling menghormati dan memelihara hak dan kewajiban masing-masing.

3) pemahaman tentang irama kehidupan yang menyenangkan dan yang tidak menyenangkan.

4) pemahaman dan penerimaan diri secara objektif dan konstruktif baik terkait dengan keunggulan mapun kelemahan.

5) sikap positif atau respek terhadap diri sendiri dan orang lain.

6) kemampuan melakukan pilihan secara sehat.

7) rasa tanggung jawab, yang diwujudkan dalam bentuk komitmen dalam tugas atau kewajiban.

8) kemampuan berinteraksi sosial, yang diwujudkan dalam bentuk 
hubungan persahabatan, menyelesaikan konflik baik bersifat internal maupun dengan orang lain, serta mampu mengambil keputusan secara efektif.

c. Unsur-Unsur Bimbingan Pribadi Sosial

Menurut Winkel dan Sri Hastuti (2007: 118-119) unsur-unsur bimbingan pribadi sosial adalah sebagai berikut:

a) Informasi tentang fase atau tahap perkembangan yang sedang dilalui oleh siswa remaja, antara lain tentang konflik batin dan tentang tata cara bergaul dengan baik.

b) Pengaturan diskusi kelompok kesulitan yang dialami oleh kebanyakan siswa.

c) Pengumpulan data yang relevan untuk mengenal kepribadian siswa.

d. Pendekatan Rational Emotive Therapy (RET)

1) Asumasi Dasar Pendekatan Rational Emotive Therapy (RET)

George, Cristiani \& Cottone (dalam Hartono \& Boy 2012: 132133) menyatakan bahwa pendekatan RET memberikan asumsi dasar bahwa hakikat manusia sebagai berikut:

a) Manusia itu unik secara rasional dam irasional. Kenunikan itu ditunjukkan dalam cara berfikir dan berperilaku secara rasional.

b) Gangguan emosi dan psikologis adalah hasil dari berpikir yang irasional dan tidak logis (irrational and illogical thingking).

c) Pemikiran yang irasional merupakan hasil dari belajar yang tidak logis biasanya berasal dari orang tua atau budaya.

d) Manusia merupakan binatang verbal, di mana dalam berpikir menggunakan simbol atau bahasa. Jika pikiran bekerja sama dengan emosi, pikiran yang negatif akan muncul jika emosi seseorang itu terganggu.

e) Gangguan emosional yang terus menerus akan menimbulkan verbalisasi di mana tidak ditentukan oleh keadaan atau kejadian nyata diluar diri, tetapi pada persepsi dan sikap terhadap kejadian tersebut.

f)Individu mempunyai sumber-sumber untuk mengaktualisasikan potensi dirinya dan dapat mengubah pribadi dan hubungan sosialnya.

g) Pikiran negatif mengenai kekalahan diri dan emosi harus dilawan dengan cara mereorganisasi pikiran dan persepsi, sehingga akan mengarahkan seseorang untuk berpikir secara lebih logis dan rasional.

Sedang menurut Winkel dan Sri Hastuti (2006) asumsi dasar pendekatan RET adalah sebagai berikut: 
1) Manusia dilahirkan dengan berbagai potensi kehidupan.

2) Kehidupan manusia pada hakekatnya bersumber dari dua kekuatan berpikir, yaitu berpikir rasional dan irasional.

3) Perilaku verbal dan berpikir pada manusia senantiasa dilakukan melalui penggunaan simbol-simbol atau bahasa.

4) Berpikir irasional merupakan kenyataan hidup manusia yang terbentuk melalui pengalaman serta proses belajar yang tidak logis, yang diperoleh melalui orang tua, keluarga, masyarakat dan kebudayaan.

Pendapat diatas pada prinsipnya menekankan bahwa asumsi dasar pendekatan rational emotive therapy ialah manusia memiliki dua sumber kekuatan berpikir, yaitu berpikir rasional dan irasional. Keunikan pada manusia ditunjukkan dalam berpikir dan berperilaku secara rasional sedangkan berpikir irasional merupakan hasil pengalaman serta proses belajar yang tidak logis biasanya berasal dari orang tua, keluaga, masyarakat dan kebudayaan. Oleh karena itu perlu adanya rational emotive therapy agar pemikiran siswa menjadi rasional.

e. Tujuan Konseling Rational Emotive Therapy

Hartono \& Boy (2012: 137) menyatakan bahwa tujuan konseling dalam terapi rasional emotif sebagai berikut:

1) Mendemonstrasikan kepada konseli bahwa verbalisasi diri (selfverbalization) merupakan sumber gangguan emosi.

2) Menunjukkan kepada konseli bahwa verbalisasi diri adalah tidak logis dan tidak rasional.

3) Mengeluarkan pemikiran sehingga verbalisasi diri dapat lebih logis dan efisien, dan tidak berhubungan dengan emosi negatif dan perilaku kekalahan diri.

Sedangkan menurut Gerald Corey (1975) tujuan konseling terapi rational emotive adalah sebagai berikut:

a) Memperbaiki dan mengubah: sikap, persepsi, cara berpikir, berkeyakinan serta pandangan-pandangan individu yang irasional menjadi rasional sehingga individu (siswa) dapat mengoptimalkan perilaku kognitif dan afektif secara positif.

b) Menghilangkan gangguan emosional yang dapat merusak diri sendiri, seperti rasa benci, rasa takut, rasa bersalah dan system keyakinan yang keliru dengan cara melatih individu untuk menghadapi kenyataan hidup secara rasional.

Bertolak beberapa pendapat diatas tujuan konseling dalam terapi rational emotive yaitu menghilangkan gangguan emosional yang dapat 
merusak diri sendiri memperbaiki dan merubah sikap, persepsi, cara berpikir, berkeyakinan serta pandangan-pandangan individu yang rasional menjadi rasional sehingga individu dapat mengoptimalkan perilaku kognitif dan afektif secara posotif.

f. Teknik Konseling Sebagai Upaya membantu Perubahan

Hartono \& Boy (2012: 140-143) menjelaskan usaha konselor untuk mengubah diri konseli secara langsung, maka terapis menggunakan beberapa teknik konseling sebagai berikut:

1) Terapi kognif

Teknik kognitif mempersoalkan keyakinan irasional yang dimiliki konseli. Hanya dalam pelaksanaannya digunakan prosedur verbal. Setelah itu terapis berusaha mengajari konseli agar dapat berhubungan dengan pernyataan diri (self-statement).

2) Humor

Humor dapat digunakan untuk menciptakan rapport dan sebagai teknik untuk membuka diri konseli, dimana konselor menunjukkan adanya ketidaksempurnaan atau kelemahan yang sebaiknya bisa diterima oleh setiap manusia.

3) Teknik emotif

Teknik emotif dapat digunakan beberapa cara diantaranya sebagai berikut:

(a) Bermain peran (role playing)

Terapis menggunakan teknik ini agar konseli dapat berinteraksi dengan orang lain. Tujuannya adalah agar emosi konseli yang terpendam dapat keluar.

(b) Bahasa emosional yang diubah (emotionally changed language)

Para terapis RET sering kali menggunakan intonasi kata-kata secara emosional, frasa (frase) dan kalimat yang biasanya digunakan oleh konseli.

(c) Teknik perilaku

Ellis (dalam Corey Dalam Hartono \& Boy (2012: 142) terapi perilaku, RET menggunakan beberapa teknik yang digunakan dalam pendekatan perilkau seperti operant conditioning, prinsipprinsip pengaturan diri (self-menagement), disensitisasi sistematis (systematic desentization), pengkondisian instrumental (instrumental conditioning), bio feedback, teknik relaksasi (relaxation teecniques) dan modeling. 
Albert Ellis (dalam Ibnu Mahmudi 2006: 38-39) teknik-teknik emotif-eksperiensial yang digunakan dalam RET antara lan adalah sebagai berikut:

1) Teknik asertif training

Teknik asertif training digunakan untuk melatih, mendorong dan membiasakan konseli secara terus menerus menyesuaikan diri.

2) Teknik sosiodrama

Teknik sosiodraman digunakan untuk mengekspresikan berbagai jenis perasaan yang menekan dari konseli melalui suatu suasana yang dramatis, sehingga konseli secara bebas mengungkapkan dirinya sendiri.

3) Teknik self modeling

Teknik ini digunakan dengan meminta konseli "berjanji" atau berkomitmen untuk menghilangkan perasaan atau perilaku tertentu.

4) Teknik imitasi

Teknik yang digunakan dimana klien diminta untuk menirukan secara terus menerus suatu model perilaku tertentu dengan maksud merubah perilakunya sendiri yang negative.

g. Bimbingan Sosial Pribadi dengan Pendekatan Rational Emotive Therapy

Berdasarkan uraian di atas, maka yang dimaksud dengan bimbingan pribadi-sosial dengan pendekatan rational emotive therapy adalah merupakan layanan bantuan dalam mengatasi masalah-masalah pribadi dan sosial, yang dihadapi siswa terhadap lingkungan disekitarnya. Cara yang ditempuh adalah dengan cara mengubah pola berfikir siswa yang irrasional menjadi rasional, sehingga siswa dapat membiasakan diri untuk berfikir positif terhadap lingkungannya. Melalui layanan bimbingan pribadi-sosial dengan pendekatan rational emotive therapy diharapkan siswa mampu menyesuaikan diri terhadap lingkungannya, siswa dapat membiasakan diri berfikir rational, dan menciptakan hubungan yang harmonis di lingkungan sekolah.

\section{Interaksi Sosial Dengan Teman Sebaya}

a. Interaksi Sosial

1) Pengertian Interaksi Sosial

Elly, Kama dan Ridwan (2006: 86) menyatakan bahwa inti interaksi sosial adalah proses berkomunikasi yang berlangsung dan saling mempengaruhi dalam pikiran dan tindakan.

Booner (dalam Elly dkk 2006: 87) menyatakan bahwa hakikat interaksi sosial adalah hubungan antara dua individu atau lebih yang saling mempengaruhi perilaku individu yang lainnya. 
Bimo Walgito (2003: 57) menyatakan interaksi sosial ialah hubungan antara individu satu dengan individu yang lain, yang dapat mempengaruhi individu lain atau sebaliknya.

Jadi hakikat interaksi sosial adalah hubungan timbal balik antara dua orang atau lebih,dan masing-masing orang yang terlibat di dalam peroses komunikasi itu memainkan peran secara aktif, sehingga saling mempengaruhi perilakunya.

2) Faktor-faktor Yang Mempengaruhi Interaksi Sosial

Elly, Kama dan Ridwan (2006: 88) menyatakan beberapa faktor yang mempengaruhi interaksi sosial, yaitu sebagai berikut:

a) Faktor imitasi atau proses peniruan, yaitu siswa meniru perilaku orang lain yang dianggap berperan dalam hidupnya. Faktor imitasi mempunyai peranan sangat positif dalam kehidupan, yaitu bahwa imitasi dapat membawa seseorang untuk mematuhi kaidah-kaidah yang berlaku.

b) Faktor sugesti, yang merupakan pengaruh psikis, baik yang datang dari dirinya sendiri maupun dari orang lain, yang pada umumnya diterima tanpa adanya daya kritik. Sugesti dibutuhkan ketika siswa melakukan interaksi sosial, sehingga dapat memberi suatu pandangan mengenai sikap dari dirinya yang kemudian dapat diterima oleh orang lain.

c) Faktor identifikasi, yaitu suatu dorongan untuk menjadi identik (sama) dengan orang lain, baik secara lahiriah maupun batiniah. Identifikasi dibutuhkan saat melakukan interaksi sosial karena seseorang mendalami proses sugesti maupun imitasi ketika hubungan interaksi sedang berlangsung.

d) Faktor simpati, yaitu perasaan tertariknya orang yang satu terhadap orang yang lain. Simpati pada prinsipnya dibutuhkan dalam interaksi sosial karena adanya simpati maka seseorang dengan sendirinya akan tertarik pada orang lain yang dianggap tingkah laku orang lain sangat menarik bagi dirinya.

3) Syarat-syarat Terjadinya Interaksi Sosial

Elly, et.al (2006: 90) mengemukakan persyaratan agar terjadi interaksi sosial sebagai berikut :

(a) Adanya Kontak Sosial

Kontak sosial secara harfiah berarti bersama-sama menyentuh. Ketika melakukan hubungan interaksi sosial seseorang tidak perlu mengadakan hubungan dengan orang lain secara kontak fisik langsung, melainkan bisa orang berbicara melalui telepon, berkirim berita dengan menggukan surat.

(b) Adanya Komunikasi 
Komunikasi merupakan proses menyampaikan pesan dari satu pihak ke pihak lain sehingga terjadi pengertian bersama.

\section{b. Teman Sebaya}

1) Pengertian Teman Sebaya

Hetherington \& Parke (dalam Desmita 2006:145) mengartikan teman sebaya (peer-group) adalah sebuah kelompok sosial yang memiliki kesamaan sosial atau memiliki kesamaan ciri-ciri dan kesamaan tingkat usia.

Lewis \& Rosenblum (dalam Desmita 2006:145) berpendapat bahwa teman sebaya sebagai kesamaan tingkah laku psikologis.

Santrock (2003:219) mengartikan teman sebaya (peer-group) adalah anak-anak atau remaja dengan tingkat usia atau tingkat kedewasaan yang sama.

Bertolak dari beberapa pengertian diatas maka menurut peneliti teman sebaya adalah kelompok individu (anak-anak, remaja atau orang dewasa) yang mempunyai usia yang sama untuk melakukan hubungan kerja atau bermain bersama

2) Fungsi Kelompok Teman Sebaya

Diane, Sallly \& Ruth (2008: 617) menyatakan bahwa kelompok teman sebaya berfungsi sebagai sumber afeksi, simpati, pemahaman, panduan moral, tempat bereksperimen, dan setting untuk memperoleh otonomi dan independensi dari orang tua.

Papalia Old Reldman (2009-95) berpendapat bahwa fungsi teman sebaya adalah merupakan sumber informasi dan perbandingan

3) Interaksi Sosial dengan Teman Sebaya

Berdasarkan urairan tentang interaksi sosial dan teman sebaya diatas maka pengertian interaksi sosial dengan teman sebaya adalah hubungan persahabatan antara anak-anak atau orang dewasa untuk melakukan kerja sama atau belajar bersama dalam arti yang luas. Dengan demikian yang dimaksud interaksi sosial dengan teman sebaya di sekolah adalah jalinan persahabatan antar siswa yang mempunyai tujuan untuk saling bekerja sama dalam mewujudkan prestasi akademik di sekolah, untuk saling mengembangkan diri sebagai pribadi yang senantiasa tumbuh dan berkembang dalam bidang olah raga dan kesenian.

\section{Metode Penelitian}

\section{Tempat dan Waktu Penelitian}

Penelitian dilaksanakan di MAN Dolopo Madiun, yang beralamat di Jalan Raya Ponorogo, Dolopo, Kabupaten Madiun. MAN Dolopo Madiun berada di desa Glonggong Kecamatan Dolopo Kabupaten Madiun, Km 17,7 
sebelah selatan wilayah Kabupaten Madiun. Waktu penelitian dilaksanakan pada bulan Februari sampai dengan bulan Juni 2013.

\section{Populasi dan Sampel Penelitian}

Populasi penelitian adalah siswa kelas XI MAN Dolopo Kabupaten Madiun yang berjumlah 132. Sampel penelitian ditetapkan sebanyak 20 siswa yang memiliki interaksi dengan teman sebaya yang rendah. Sampel penelitian ditetapkan dengan teknik purposive sampling. Hal tersebut secara metodologis telah memenuhi syarat karena menurut pendapat Vitalis DS (2012:10) yang menjelaskan bahwa penentuan sekelompok individu atas dasar ciri-ciri atau sifat-sifat tertentu yang dipandang memiliki keterkaitan dengan ciri-ciri atau sifat-sifat tertentu populasi yang telah diketahui sebelumnya.

\section{Pengumpulan Data Penelitian}

Data penelitian diperoleh dengan teknik angket tertutup. Angket penelitian disusun untuk memperoleh data tentang interaksi sosial dengan teman sebaya antara sebelum (sebagai upaya diagnosis) dan sesudah diberi layanan bimbingan dengan pendekatan rational emotive therapy. Hasil isian angket antara sebelum dan sesudah diberi layanan layanan bimbingan dengan pendekatan rational emotive therapy kemudian dibandingkan untuk menguji signifikansinya.

Angket penelitian disediakan disusun dalam bentuk pilihan ganda, dengan empat alternatif jawaban: a, b, c, dan d. Model skoring hasil isian angket mengacu pendapat Sugiyono (2013) tentang skala Likert, dengan ketentuan sebagai berikut: huruf a (selalu): skor 4, huruf b (sering): skor 3, huruf c (kadang-kadang): skor 2, huruf d (tidak pernah): skor 1 .

\section{Teknik Analsisis Data}

Teknik analisis data penelitian dengan rumus bangun $t$-score sebagai berikut:

$$
t=\frac{M d}{\sqrt{\frac{\sum X^{2} d}{N(N-1)}}}
$$

(Suharsimi Arikunto, 2010: 349)

Keterangan:

$\mathrm{M}_{\mathrm{d}} \quad=$ mean dari perbedaan pre test dan post test (post test - pre test)

$\mathrm{x}_{\mathrm{d}} \quad=$ deviasi masing - masing subyek $(\mathrm{d}-\mathrm{Md})$

$\sum \mathrm{x}_{\mathrm{d}}^{2}=$ jumlah kuadrat deviasi

$\mathrm{N} \quad=$ subyek pada sampel

d.b. = ditentukan dengan $\mathrm{N}-1$ 


\section{Deskripsi Data}

Berdasarkan hasil analisis data penelitian angket interaksi sosial dengan teman sebaya, yang dianalisis dengan menggunakan bantuan program Microsoft Office Exel 2007 dan SPSS 16.0, maka data tersebut dapat dideskripsikan sebagai berikut :

1. Skor Angket Interaksi Sosial Dengan Teman Sebaya Sebelum Diberi Bimbingan Sosial Pribadi Dengan Pendekatan Rational Emotive Therapy

Berdasarkan hasil skor angket data yang diperoleh dari sampel sebanyak $\mathrm{N}=20$ siswa, dengan rentang skor antara 20-80, dapat didiskripsikan sebagai berikut : (a) Mean =46,7, (b) Median =45, (c) Modus =40, (d) Skor terendah $=39$, dan (e) Skor tertinggi $=60$

Bertolak dari deskripsi data di atas maka dapat dilaporkan distribusi frekuensi bergolong dan bentuk grafik batang sebagai berikut:

Tabel 1 Distribusi Frekuensi Skor Angket Interaksi Sosial dengan Teman Sebaya Sebelum Diberi Bimbingan Sosial Pribadi dengan Pendekatan Rational Emotive Therapy

\begin{tabular}{|c|c|c|c|}
\hline No & $\begin{array}{c}\text { Interval Nilai } \\
(\mathrm{I})\end{array}$ & $\begin{array}{c}\text { Titik Tengah } \\
\left(\mathrm{X}_{\mathrm{i}}\right)\end{array}$ & Frekuensi (f) \\
\hline 1 & $59-61$ & 60 & 2 \\
\hline 2 & $56-58$ & 57 & 1 \\
\hline 3 & $53-55$ & 54 & 3 \\
\hline 4 & $50-52$ & 51 & 2 \\
\hline 5 & $47-49$ & 48 & 1 \\
\hline 6 & $44-46$ & 45 & 1 \\
\hline 7 & $41-43$ & 42 & 2 \\
\hline 8 & $37-40$ & 39 & 8 \\
\hline
\end{tabular}

Berdasarkan hasil distribusi frekuensi skor angket diatas dapat dibuat grafik sebagai berikut:

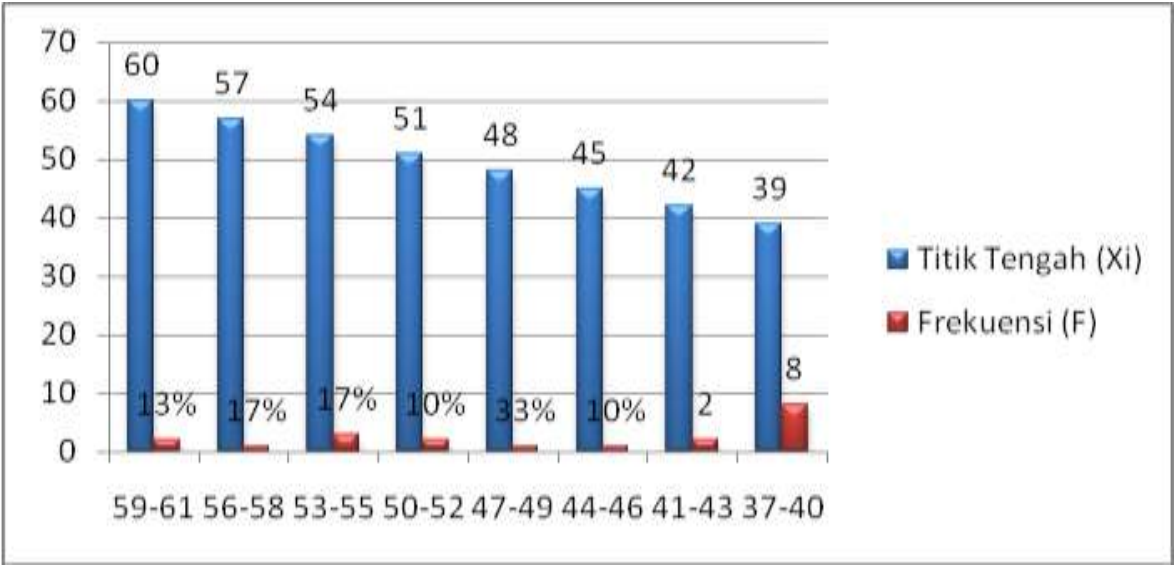

Grafik 1. Skor Angket Interaksi Sosial dengan Teman Sebaya Sebelum diberi Bimbingan Sosial Pribadi dengan Pendekatan Rational Emotive Therapy 


\section{Deskripsi Skor Setelah Diberikan Treatmen Bimbingan Sosial Pribadi dengan Pendekatan Rational Emotive Therapy}

Berdasarkan hasil skor angket dengan $\mathrm{N}=20$ siswa, dengan rentang skor antara 20-80, maka data tersebut dapat didiskripsikan sebagai berikut: (a) Mean $=54,6$, (b) Median $=45$, (c) Modus $=56$, (d) Skor terendah $=40$, dan (e) Skor tertinggi $=64$.

Bertolak dari deskripsi data di atas maka dapat dilaporkan distribusi frekuensi bergolong dan bentuk grafik batang sebagai berikut:

Tabel 2. Distribusi Frekuensi Skor Angket Interaksi Sosial dengan Teman Sebaya Sesudah Diberi Bimbingan Sosial Pribadi dengan Pendekatan Rational Emotive Therapy

\begin{tabular}{|c|c|c|c|}
\hline No & $\begin{array}{c}\text { Interval Nilai } \\
\text { (I) }\end{array}$ & $\begin{array}{c}\text { Titik Tengah } \\
(\mathrm{Xi})\end{array}$ & $\begin{array}{c}\text { Frekuensi } \\
\text { (f) }\end{array}$ \\
\hline 1 & $61-63$ & 62 & 4 \\
\hline 2 & $58-60$ & 59 & 3 \\
\hline 3 & $55-57$ & 56 & 7 \\
\hline 4 & $52-54$ & 53 & 1 \\
\hline 5 & $49-51$ & 50 & 1 \\
\hline 6 & $46-48$ & 47 & 0 \\
\hline 7 & $43-45$ & 44 & 2 \\
\hline 8 & $39-42$ & 40 & 2 \\
\hline
\end{tabular}

Berdasarkan hasil distribusi nilai diatas dapat dibuat grafik sebagi berikut:

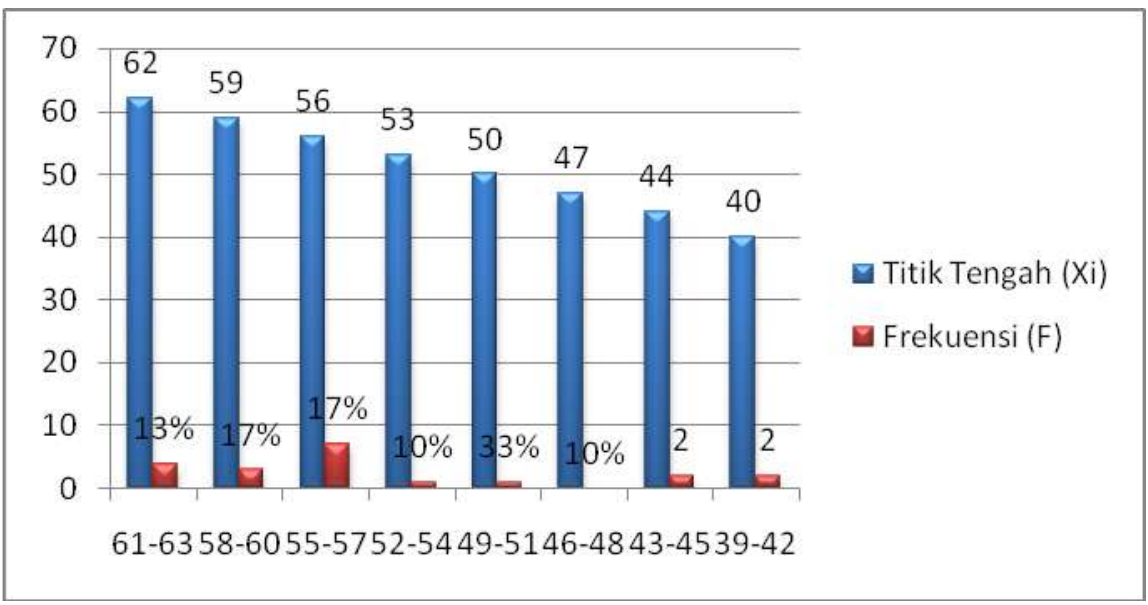

Grafik 2. Skor Angket Interaksi Sosial dengan Teman Sebaya Sesudah diberi Bimbingan Sosial Pribadi dengan Pendekatan Rational Emotive Therapy 


\section{Hasil Analisis Data}

Analisis data penelitian menunjukkan: harga $t_{\text {hitung }}=3,95$, dan harga $t_{\text {tabel }}$ dengan d.b $=\mathrm{N}-1=18$ adalah 2,101/Taraf signifikan $=5 \%$. Jadi $t_{\text {hitung }}$ lebih besar dibandingkan $t_{\text {tabel }}=(3,95>2,101)$. Jadi signifikan, sehingga harus dinyatakan bahwa: "Ada pengaruh bimbingan pribadi-sosial dengan pendekatan rational emotive therapy untuk meningkatkan interaksi sosial dengan teman sebaya".

\section{Simpulan}

Bertolak dari hasil analisis data maka dapat disimpulkan bahwa: "Ada pengaruh bimbingan pribadi-sosial dengan pendekatan rational emotive therapy untuk meningkatkan interaksi sosial dengan teman sebaya pada siswa kelas XI MAN Dolopo Kabupaten Madiun tahun pelajaran 2012/2013”.

Atas dasar simpulan di atas maka dikemukakan saran-saran sebagai berikut: (a) pendekatan rational emotive therapy dapat dicoba dikembangkan sebagai model pembelajaran di sekolah, dan (b) layanan bimbingan pribadi sosial perlu diprogramkan bagi siswa khususnya dalam mengintensifkan interaksi bagai para remaja di sekolah.

\section{Daftar Pustaka}

Achmad Juntika Nurihsan.2006. Bimbingan dan Konseling. Berbagai Latar Kehidupan. Bandung: PT Refika Aditama.

Bimo Walgito.2003. Psikologi Sosial. Suatu Pengantar. Yogyakarta: Andi.

Desmita.2006. Psikologi Perkembangan. Bandung: PT. Remaja Rosdakarya.

Diane E. Papalia, Sally, Ruth. 2008. Human Development. Psikologi Perkembangan. Jakarta: Kencana.

Dewa Ketut Sukardi dan Desak PE Nila. 2008. Proses Bimbingan dan Konseling di Sekolah. Jakarta: Rineka Cipta.

Elly, Kama dan Ridwan. 2006. Ilmu Sosial dan Budaya Dasar. Jakarta: Kencana Prenada Media Group.

Hartono dan Boy. 2012. Psikologi Konseling. Edisi Revisi. Jakarta: Kencana Prenada Media Group.

Ibnu Mahmudi.2006. Model-Model Konseling. Madiun: IKIP PGRI Madiun.

John W Santrock.2003. Adolescence. Perkembangan Remaja. Jakarta: Erlangga. 2007. Remaja. Jakarta: Erlangga.

2009. Psikologi Pendidikan Educational Psychology. Jakarta:

Salemba Humanika.

Papalia Old Reldman. 2009. Human Development. Jakarta: Salemba Humanika.

Sarlito W Sarwono. 2009. Pengantar Psikologi Umum. Jakarta: Raja Grafindo Press.

Sugiyono.2012. Metode Penelitian Pendidikan Pendekatan Kuantitatif, Kualitatif, dan $R \& D$. Bandung: Alfabeta.

Suharsimi Arikunto.2009. Menejemen Penelitian. Jakarta: Rineka Cipta. 
.2010. Prosedur Penelitian. Suatu Pendekatan Praktik. Jakarta: Rineka Cipta.

Syamsu Yusuf dan Ahmad Juntika. 2010. Landasan Bimbingan dan Konseling. Bandung: PT Remaja Rosdakarya.

Vitalis DS. 2009. Evaluasi Pendidikan. Madiun: IKIP PGRI Madiun.

2009. Profesionalisme Bimbingan \& Konseling. Madiun: IKIP PGRI Madiun.

.2012. Statistik Inferensial ( Statistik II ). Madiun: IKIP PGRI Madiun.

W.S Winkel dan Sri Hastuti.2006. Bimbingan dan Konseling. Di Institusi Pendidikan. Yogyakarta: Media Abadi. 